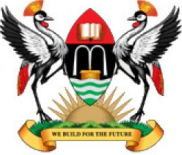

East African School of

Higher Education Studies \& Development
Makerere Journal of Higher Education

ISSN: 1816-6822; 5 (1) (2013) 81 ï 90

DOI: http://dx.doi.org/10.4314/majohe.v5i1.6

(C) The Author(s) 2013

Reprints \& permission: EASHESD

http://ajol.info/majohe

\title{
Status of Technical and Vocational Education in Rural Institutions in Delta State Nigeria
}

\author{
Chinyere Shirley Ayonmike ${ }^{1}$ \\ ${ }^{1}$ Department of Technical and Business Education, Delta State University [Email: \\ chinyereshirley@ymail.com]
}

\begin{abstract}
This study was aimed at assessing the state of technical and vocational education in rural institutions in Delta State. Three research questions guided the study. A sample size of fifty (50) principals from 50 rural institutions in Delta State was used for the study. Data were collected using a questionnaire. The study reveals that the state of human resources for teaching technical and vocational subjects in rural institutions is poor. Also, the state of infrastructural facilities is inadequate. Based on the findings, it was recommended that Delta State government should employ qualified technical and vocational subject teachers and provide adequate infrastructural facilities for teaching technical and vocational subjects in rural institutions in the State. In addition, community leaders should donate consumable materials, machines and infrastructural facilities to rural institutions for teaching and learning technical and vocational subjects.
\end{abstract}

Keywords: Technical and vocational education; Higher education reform.

\section{$1 \quad$ Introduction}

According to UNESCO (2001), Technical and Vocational Education (TVE) is used as a comprehensive term referring to those aspects of the educational process involving in addition to general education, the study of technologies and related sciences, and the acquisition of practical skills, attitudes, understanding and knowledge relating to occupation in various sectors of economic and social life. More so, the National Policy on Education (Federal Republic of Nigeria, 2004), states that TVE refers to a range of learning experiences which are relevant to the world of work. However, Jean (2003:17) in Onjewu (nd.), Technical Education designates the aspect of the technical process which in addition to general instruction, involve the study of closely 
related science and the acquisition of practical capacities, attitudes, understanding and knowledge related to trades of a different section of economic and social life. It is not necessarily vocational in the sense of preparing directly for the exercise of a trade or job. This teaching can be part of a study programme in progress with the purpose of continuing to a higher level of studies.

\subsection{Goals of TVE in Nigeria}

According to Federal Republic of Nigeria (FRN, 2004), the preparatory aspect of pre-vocational training offered to students is for the purpose of;

1. Introduction into world of technology and appreciation of technology towards interest arousal and choice of a vocation.

2. Acquiring technical skills

3. Exposing students to career awareness by exploring usable options in the world of work, and

4. Enabling youths to have an intelligent understanding of increasing complexity of technology

Consequently, the goals of Technical and Vocational Education (TVE) shall be to;

1. Provide sciences, technology and applied sciences, technology and business particularly at craft, advanced craft, and technical levels.

2. Provide the technical knowledge and vocational skills necessary for agricultural, commercial and economic development.

3. Give training and impart the necessary skills to individual who shall be self-reliant economically.

However, the above goals of TVE in institutions are unique but the problem in this study is that, there is information gap in respect of the state of TVE in rural institutions in Delta State since the state of human and material resources for teaching and learning TVE subjects in rural schools are not known. Therefore, this study was conducted to assess the state of TVE in rural institutions in Delta State.

\subsection{Structure of TVE Curriculum in Nigeria}

In line with the National Policy objectives on career-oriented education as outlined in the National Policy on Education document and with reference to the curricula for JSS and SSS are designed to achieve both technological and economic advancement of Nigeria (Ekpenyong, 2011). Also, Ekpenyong posited that, the following are structures of prevocational and vocational 
courses in Nigerian institutions as contained in the 2004 edition of the National Policy on Education (FRN,2004). They are all elective subjects except Introductory Technology which has been listed as a core subject at the JSS level. At the JSS level, the pre-vocational elective subjects include; Agricultural Science, Business Studies, Home Economics, Local Crafts, Computer Education (Information Technology), Fine Arts (Creative Arts), Music, and Introductory Technology (Basic Technology). However, at the SSS level, the vocational education elective subjects include; Agricultural Science, Applied electricity, Bookkeeping and Accounting, Auto Mechanic, Commerce, Computer Education, Electronic, Clothing and Textiles, Food and Nutrition, Home Management, Metal Work, Technical Drawing, Woodwork, Shorthand, Typewriting, Fine Arts and Music.

\subsection{Challenges in the Implementation of TVE in Institutions}

According to Mohammed (2005), one of the problems of Technical and Vocational Education in Nigeria is the lack of motivated teachers and the reason for this lack of motivation could easily be traced to the low esteem of the teachers. More so, Onjewu (nd.) posited that the lack of funds on the other hand affects other essentials needed in the implementation of technical education like the provision of teaching aids, furnishing of offices, laboratories, workshops and even basic infrastructures like classroom, seats and tables, so that a common sight to find students of architecture for instance sharing a table where each ideally should have one because of the technical nature of their course. According to Ekpenyong (2011), there are a number of factors, which have in various proportions impeded the smooth implementation of the goals and objectives of Technical and Vocational Education and Training(TVET). Some of the outstanding factors affecting the implementation of TVET include;

1. Inadequate supply of technical teachers

2. Inadequate supply of equipment

3. Misinterpretation of policy and public perception of vocational technical education.

4. Technical college-industry relationship problem

5. Poor condition of services of technical teachers.

6. Inadequate guidance and placement services for technical students.

Consequently, UNESCO (2009) identified some issues of TVET, which include;

1. Low quality

2. Geographical, gender and economic inequalities

3. Poor public perception

4. Weak monitoring and evaluation mechanisms 
5. Inadequate financing, poor management and ill-adapted organisational structures.

6. The low enrolment in formal TVE at.

7. The relevance of content of TVET.

8. The dearth of textbooks

9. Shortage of qualified and skilled instructors and teachers

10. Investment in TVET is very low

However, the National Board for Technical Education (NBTE, 2011), opined that, the underlining challenges of TVET sector include; low societal recognition, which translate to low enrolment and inadequate skilled workforce, obsolete instructional facility, inadequate funding, poor staffing, poor linkages with industry and general deficiency in quality. In addition, evaluation in all sectors of education tends to be by conventional examinations, which generally does not factor in practical techniques in the industry.

\subsection{Statement of Problem}

The state of Technical and Vocational Education (TVE) in rural institutions in Delta State needs attention. This became pertinent due to the lack of information on the state of implementation of the TVE curriculum in rural institutions in particular and institutions in general in Delta State.

\subsection{Purpose of the Study}

The main objective of this study is to generate information on the state of human and material resources for teaching technical and vocational subjects in rural institutions in Delta State. The specific objectives of this study are to:

1. Assess the state of human resources (subject teachers) for teaching technical and vocational subjects in rural institutions in Delta State.

2. Assess the state of infrastructural facilities for teaching technical and vocational subjects in rural institutions in Delta State.

3. Identify ways by which community leaders can help in improving the state of technical and vocational education in rural institutions in Delta State.

\subsection{Research Questions}

The following research questions were used to guide the study;

1. What is the state of human resources (subject teachers) for teaching technical and vocational subjects in rural institutions in Delta State?

2. What is the state of infrastructural facilities used in teaching technical and vocational subjects in rural institutions in Delta State? 
3. What can community leaders do to improve the state of technical and vocational education in rural institutions in Delta State?

\subsection{Scope of the Study}

The scope of the study is on Assessment of the State of Technical and Vocational Education in Rural Institutions in Delta State. The study was limited to principals of government institutions in rural areas of Delta State.

\section{$2 \quad$ Methodology}

The survey research design was used for this study. The researcher considers this design appropriate because no variable will be manipulated in the study. The population of the study is all the four hundred and fifty three (453) public institutions principals in Delta State, Nigeria (Delta State Government, 2011). Fifty (50) principals were randomly selected from fifty (50) rural institutions (two (2) each from all the 25 Local Government Areas of Delta State).

A questionnaire was the main instrument used for collection of data for the study. The questionnaire contains 38 -items, which was on a 5 point Likert Scale were used for the study. The questionnaire has 3 parts. Part $\mathrm{A}$ is on the assessment of the availability of teachers; Part B is on the assessment of the availability of infrastructural facilities and Part $\mathrm{C}$ is on how community leaders can improve TVET in rural institutions. The questionnaire was faced validated by two lecturers in the Department of Technical and Business Education, Delta State University, Abraka, and possible corrections were made based on their suggestions. However, the pre-testing of the questionnaire was conducted with 10 respondents from rural institutions in Delta State. These respondents were not part of the real sample of the study. Thus, the internal consistency reliability co-efficient of the questionnaire assessed produced a satisfactory value of 0.73 .

The data collected were analysed using simple frequency count and group mean. Using a 5-point Likert scale in assigning points for the respondents response $(\mathrm{SA}=5, \mathrm{~A}=4, \mathrm{UD}=3, \mathrm{SD}=2, \mathrm{D}=1)$. The implication is that any response with group mean rating of 3.00 and above are accepted as óAgreeôand a group mean that is less than 3.00 is accorded to be đ́disagreeô 


\section{$3 \quad$ Findings and Discussion}

\subsection{State of Human Resources in TVE Institutions}

Table 1: State of human resources in TVE Institutions

\begin{tabular}{|c|c|c|c|c|c|c|c|}
\hline \multirow[b]{2}{*}{$\begin{array}{l}\text { Institutions have the following } \\
\text { qualified teachers: }\end{array}$} & \multicolumn{7}{|c|}{ Frequency } \\
\hline & $\begin{array}{l}5 \\
\text { SA }\end{array}$ & $\begin{array}{l}4 \\
\mathrm{~A}\end{array}$ & $\begin{array}{l}3 \\
\text { UD }\end{array}$ & $\begin{array}{l}2 \\
\text { SD }\end{array}$ & $\begin{array}{l}1 \\
D\end{array}$ & Mean & Decision \\
\hline Agricultural science & 20 & 10 & 10 & 5 & 5 & 3.70 & Agree \\
\hline Business Studies & 30 & 5 & 7 & 3 & 8 & 4.10 & Agree \\
\hline Home Economics & 40 & 2 & 1 & 4 & 3 & 4.44 & Agree \\
\hline Local Crafts & 0 & 2 & 10 & 30 & 8 & 2.12 & Disagree \\
\hline Information Technology & 2 & 6 & 5 & 30 & 7 & 2.32 & Disagree \\
\hline Fine Arts & 20 & 3 & 10 & 15 & 2 & 3.48 & Agree \\
\hline Music & 2 & 3 & 12 & 31 & 2 & 2.44 & Disagree \\
\hline Basic Technology & 3 & 7 & 3 & 7 & 30 & 1.92 & Disagree \\
\hline Book keeping and Accounting & 10 & 3 & 4 & 31 & 2 & 2.76 & Disagree \\
\hline Commerce & 7 & 3 & 6 & 29 & 5 & 2.56 & Disagree \\
\hline Clothing and Textiles & 20 & 7 & 9 & 4 & 10 & 3.28 & Agree \\
\hline Food and Nutrition & 30 & 5 & 2 & 3 & 10 & 3.84 & Agree \\
\hline Home Management & 26 & 4 & 5 & 10 & 5 & 3.72 & Agree \\
\hline Technical Drawing & 2 & 6 & 2 & 35 & 5 & 3.00 & Agree \\
\hline Woodwork & 3 & 7 & 1 & 33 & 6 & 2.36 & Disagree \\
\hline Metal work & 3 & 4 & 2 & 36 & 5 & 2.28 & Disagree \\
\hline Shorthand & 1 & 3 & 10 & 35 & 1 & 2.36 & Disagree \\
\hline Typewriting & 2 & 6 & 5 & 35 & 2 & 2.42 & Disagree \\
\hline Grand Mean & & & & & & 2.95 & \\
\hline
\end{tabular}

SA=Strongly Agree, A=Agree, UD=Undecided, SD=Strongly Disagree, D=Disagree

In Table 1, the principalsô decisions revealed that rural institutions in Delta State do not have qualified technical and vocational subjects teachers in the following subjects; Local Crafts, Computer Education/Information Technology, Music, Introductory Technology/Basic Technology, Bookkeeping and Accounting, Commerce Woodwork, Metalwork, Shorthand and Typewriting. This findings is in line with Ekpenyong (2011) who opined that, there are a number of factors, which have in various proportions impeded the smooth implementation of TVE, some of the outstanding ones include; inadequate supply of technical teachers and poor condition of services of technical teachers amongst others. Also, NBTE (2011) opined that, the underlining challenges of 
TVET sector include; low societal recognition and inadequate skilled workforce.

\subsection{State of Infrastructure in TVE Institutions}

Table 2: State of Infrastructure in TVE Institutions

\begin{tabular}{|c|c|c|c|c|c|c|c|}
\hline \multirow[b]{2}{*}{ Rural Institutions have adequate; } & \multicolumn{6}{|c|}{ Frequency } & \multirow[b]{2}{*}{ Decision } \\
\hline & $\begin{array}{l}5 \\
\text { SA }\end{array}$ & $\begin{array}{l}4 \\
\mathrm{~A}\end{array}$ & $\begin{array}{l}3 \\
\text { UD }\end{array}$ & $\begin{array}{l}2 \\
\text { SD }\end{array}$ & $\begin{array}{l}1 \\
\mathrm{D}\end{array}$ & Mean & \\
\hline Food and Nutrition laboratory & 1 & 3 & 5 & 36 & 5 & 2.18 & Disagree \\
\hline Basic Technology Workshop & 2 & 0 & 0 & 38 & 10 & 1.92 & Disagree \\
\hline Clothing and Textile Workshop & 0 & 0 & 10 & 37 & 3 & 2.14 & Disagree \\
\hline Technical Drawing Room & 2 & 0 & 0 & 45 & 3 & 2.06 & Disagree \\
\hline Creative Arts Studio & 0 & 0 & 10 & 35 & 5 & 2.10 & Disagree \\
\hline Information Technology Laboratory & 1 & 2 & 5 & 38 & 4 & 2.16 & Disagree \\
\hline Local Craft Workshop & 1 & 1 & 5 & 40 & 3 & 2.14 & Disagree \\
\hline Hand tools & 15 & 2 & 1 & 30 & 2 & 2.96 & Disagree \\
\hline Portable Power Tools & 3 & 2 & 5 & 37 & 3 & 2.30 & Disagree \\
\hline Power Tools & 0 & 0 & 5 & 43 & 2 & 2.06 & Disagree \\
\hline Consumables for Practical & 3 & 3 & 3 & 37 & 5 & 2.28 & Disagree \\
\hline Woodwork Workshop & 2 & 2 & 10 & 35 & 1 & 2.38 & Disagree \\
\hline Metalwork Workshop & 3 & 2 & 5 & 25 & 15 & 2.06 & Disagree \\
\hline Music Studio & 2 & 2 & 0 & 44 & 2 & 2.16 & Disagree \\
\hline Typewriting Studio & 1 & 1 & 5 & 3 & 40 & 1.40 & Disagree \\
\hline Grand Mean & & & & & & 2.15 & \\
\hline
\end{tabular}

In Table II, the principals decisions shows that rural institutions do not have the required infrastructural facilities used for teaching Technical and Vocational subjects. These facilities include; Food and Nutrition Laboratory, Basic Technology Workshop, Clothing and Textile Workshops, Technical Drawing Room, Creative Arts Studio, Information Technology Laboratory, Local Crafts Workshop, Hand Tools, Portable Power Tools, Consumables for practical, workshops, Music Studio and Typewriting Studio/Laboratory. However, this findings is in accordance with UNESCO (2009), some of the identified issues of TVET include; inadequate financing, poor management and ill-adapted organisational structure. Infrastructural facilities for technical and vocational education are very expensive. The implication is that, TVE requires adequate funding in other to combat the challenges of lack of required infrastructural facilities. In addition Ekpenyong (2011) states that, inadequate supply of 
equipment impedes the smooth implementation of technical and vocational education.

\subsection{Role of Community Leaders in Improving TVE}

Table 3: Role of Community Leaders in Improving TVE

\begin{tabular}{|c|c|c|c|c|c|c|c|}
\hline \multirow{2}{*}{$\begin{array}{l}\text { Community Leaders can help in } \\
\text { improving TVE in rural institutions } \\
\text { through the following; }\end{array}$} & \multicolumn{6}{|c|}{ Frequency } & \multirow[b]{2}{*}{ Decision } \\
\hline & $\begin{array}{l}5 \\
\text { SA }\end{array}$ & $\begin{array}{l}4 \\
A\end{array}$ & $\begin{array}{l}3 \\
\text { UD }\end{array}$ & $\begin{array}{l}2 \\
\text { SD }\end{array}$ & $\begin{array}{l}1 \\
D\end{array}$ & Mean & \\
\hline Provision of consumables for practical & 35 & 5 & 2 & 3 & 5 & 4.04 & Agree \\
\hline $\begin{array}{l}\text { Provision of fund to employ contract } \\
\text { technical and vocational subject } \\
\text { teachers }\end{array}$ & 40 & 2 & 1 & 5 & 2 & 4.50 & Agree \\
\hline $\begin{array}{l}\text { Building and equipping technical and } \\
\text { vocational subjects laboratory and } \\
\text { workshop }\end{array}$ & 36 & 5 & 5 & 2 & 2 & 4.42 & Agree \\
\hline $\begin{array}{l}\text { Organizing fund raising ceremony for } \\
\text { the purpose of procuring technical and } \\
\text { vocational education instructional } \\
\text { materials. }\end{array}$ & 26 & 15 & 4 & 3 & 2 & 4.20 & Agree \\
\hline $\begin{array}{l}\text { Sending appeal letters to government } \\
\text { and nongovernmental organisation to } \\
\text { address the needs of rural institutions } \\
\text { with respect to technical and } \\
\text { vocational education. }\end{array}$ & 37 & 13 & 7 & 2 & 1 & 4.26 & Agree \\
\hline Grand Mean & & & & & & 4.28 & \\
\hline
\end{tabular}

In Table 3: the principalsôresponse shows that community leaders have role to play in improving the state of technical and vocational education in rural institutions in Delta State. Some of the roles of community leaders is; provision of consumables for practical, provision of fund to employ contract technical and vocational subjects teacherôs building and equipping technical and vocational subjects laboratory and workshop, organizing fund raising ceremony for the propose of procuring technical and vocational education instructional materials and sending of appeal letters to government and nongovernmental organisation to address the needs of rural institutions with respect to technical and vocational education. This is in line with some projects which has been built by various firms operating in different communities. 


\section{Conclusion and Recommendations}

Based on the findings, it was concluded that, the rural institutions in Delta Sate lack qualified technical and vocational subjectsôteachers and also the state of infrastructural facilities is very poor. Hence, the implementation of TVE in rural institutions needs to be addressed by government and non-governmental organisation through the provision of the required infrastructural facilities for teaching technical and vocational subjects and the recruitment of qualified technical and vocational subject teachers. Based on the findings the following recommendations were made;

1. Delta State Government should employ qualified technical and vocational subject teachers in all the rural institutions in Delta State. However, the State Commissioner of Basic and Secondary Education, Delta State Ministry of Basic and Secondary Education, Delta State Post Primary Education Board, and Delta State Civil Service Commission needs to work collectively to establish an employment scheme and committee that will be made up of TVE professionals, (from industries and academic institutions) educational policy makers, and educational administrators that will be in charge of selection and recruitment of TVE subject teachers based on their level of education, competence and mastery in subject area, and ability to inculcate the curriculum content to the students. By doing this, the issue of lack of qualified and professional TVE subject teacher will be addressed and this will enhance studentsôperformance, and the achievement of the goals of TVE.

2. Government should provide the required infrastructural facilities for teaching technical and vocational subjects in rural institutions. This could be achieved through the introduction of TVE Rural Education Development Fund. The fund will be generated from tax imposed on industries, non public servants, and public servants for the purpose of improving infrastructural facilities in rural institutions. This will lead to increase in enrolment of students in rural institutions because of the improved infrastructural facilities in the rural schools, parents will be discourage from enrolling their children in urban institutions which are usually far from their home. Also, it will make teachers and students to be interested in the teaching and learning process.

3. Community leaders should provide consumable materials for practical and also donate infrastructural facilities for teaching technical and vocational subjects in rural institutions in Delta State. This can be achieved through public private partnership. The State Ministry of Basic and Secondary Education through the school principals, teachers, students, Local Education Authority, and Parentsô Teachersô Association should write to 
community leaders to assist in the provision of resources for the purpose of teaching and learning in schools in their locality. This is achievable when the school administrators has good community relations skills which will enable the principals to interact and relate well with the people of the community who can convinced their community members and leaders to give support to the schools.

\section{References}

Delta State Government (2011). Education, basic and secondary. Retrieved $20^{\text {th }}$ September 2013 from http://deltastate.gov.ng/index.php/template/permanentsecretaries/10-the-administration/259-education-basic-and-secondary

Ekpenyong, L.E. (2011). Foundations of technical and vocational education: evolution and practice. Benin City. Ambik Press Limited.

Federal Republic of Nigeria (2004). National policy on education. Yaba, Lagos, NERDC Press $4^{\text {th }}$ Edition.

Mohammed, A.R. (2005). The role of the private sector in revamping technical education in Nigeria: building bridges to the end users. A Paper Presented at a National Workshop on Revamping Technical Education in Nigeria to Face the Challenges of Technological Development. Abuja, Nigeria. June $8^{\text {th }}-9^{\text {th }}$.

National Board for Technical Education (2011). Report of the national steering committee on the development of national vocational qualifications framework (NVQF) for Nigeria. Retrieved July 24, 2012 from http://www.google.com.ng.

UNESCO (2001). Revised recommendations concerning technical and vocational education. Retrieved July 24, 2012 from http://www.google.com.ng

UNESCO (2009). Workshop on revitalizing TVET provision in ECOWAS Countries. Final Workshop Report. Retrieved July 24, 2012 from http://www.unesco.org. 